Southern Methodist University

SMU Scholar

\title{
The African-American Child Welfare Act: A Legal Redress for African-American Disproportionality in Child Protection Cases
}

Jessica Dixon Weaver

Southern Methodist University, Dedman School of Law

\section{Recommended Citation}

Jessica Dixon, The African-American Child Welfare Act: A Legal Redress for African-American Disproportionality in Child Protection Cases, 10 Berkeley J. Afr.-Am. L. \& Pol'y 109 (2008)

This document is brought to you for free and open access by the Faculty Scholarship at SMU Scholar. It has been accepted for inclusion in Faculty Journal Articles and Book Chapters by an authorized administrator of SMU Scholar. For more information, please visit http://digitalrepository.smu.edu. 


\section{The African-American Child Welfare Act:}

\section{A Legal Redress for African-American Disproportionality in Child Protection Cases}

\section{Jessica Dixon*}

\section{INTRODUCTION}

"Where are the courts for the white children?"

"Why are most of the families in the Juvenile Court African-American?"

"Is there a reason that there are more African-American families in the child welfare system?"

These are questions posed to me by law students over the last six years of teaching and supervising law students in the W.W. Caruth, Jr. Child Advocacy Clinic, and in one case, by a foreign judge who was in the United States observing the juvenile court jury system. The fact that brown faces make up over half of the children in foster care in Dallas County, Texas is not a new phenomena. ${ }^{1}$ Because it is the norm for professionals working within the child welfare system, it sometimes takes a question from an outsider to jar the thought process about why there are so many African-American children in the foster care system. Professor Dorothy Roberts, in her book Shattered Bonds, sets forth clear and convincing evidence that the current child welfare system is a racist institution that disrupts, restructures, and polices Black families. ${ }^{2}$ She addresses the politics of the racial disparities in the system, how they came to be, and how current legal and social structures--ranging from criminal laws,

\footnotetext{
- Director, W.W. Caruth, Jr. Child Advocacy Clinic, Southern Methodist University Dedman School of Law. I would like to thank my colleagues at SMU Dedman School of Law for encouraging me to write this article, especially Rose Villazor. I would also like to thank all of the students who helped me tremendously with the research -- Theresa Neyland, Aaron Clinger, Katy Stein, Cyrus Manekshaw, Alex Caraveo, Megan Smith and Larry Roberts.

1. Dep't of Family and Protective Services, Tex. Health and Human Services COMM'N, DISPROPORTIONALITY IN CHILD PROTECTIVE SERVICES - STATEWIDE REFORM EFFORT BEGINS WITH EXAMINATION OF THE PROBLEM(2006).
}

2. DOROTHY ROBERTS, SHATTERED BONDS: THE COLOR OF CHILD WELFARE (2002). 
education, welfare reform, to the economy and employment trends-work together to make the problem worse. Ultimately, she argues that the high removal rate of Black children from their homes is a group-based, racial harm. ${ }^{3}$

There have been a disproportionate number of African-American children in the child welfare system for the last several decades. ${ }^{4}$ Disproportionality in this article refers to the representation of a particular racial or ethnic group of children in the system at a higher or lower percentage than their representation in the general population. Although African-American children make up 15\% of the children in this country, they comprise $37 \%$ of the children in the child welfare system. ${ }^{5}$ The fact that African-American children are represented at more than twice their number in the general population has prompted research revealing that there is disparate treatment of children and families of color by professionals. There is widespread agreement that compared to white children and families in the child welfare system, children of color and their families have less access to services and their outcomes are poorer. When a child is placed outside the home in foster care, it is the result of many previous decisions by social workers, their supervisors, agency administrators, legal professionals, and policy makers. Decisions continue to be made regarding a child once he enters state care. Recent research shows that race impacts professionals' decision making at almost every stage of the process. ${ }^{6}$ Race does matter, as evidenced by the disproportionate statistics in reporting, investigations, substantiation, placement in foster care, and exits from foster care.

This issue is significant for the United States because, despite no differences in the occurrence of child abuse among the races, an overrepresentation of African-American children in the child welfare system has been documented in all fifty states. ${ }^{7}$ The 2006 Child Welfare Symposium held at Southern Methodist University Dedman School of Law examined the issue of disproportionality and brought together many of this country's leading professionals to discuss the impact of this problem and possible solutions. Professor Roberts was the keynote speaker, and the conclusion of her address became a theme repeated throughout the conference-the current child welfare system needs to be discarded or overhauled, and a new system put in its place. This article proposes a radical change in the way African-American children

3. Id. at 228-67.

4. Robert B. Hill, Ph.D., Synthesis Of RESEARCh ON Disproportionality IN CHILD WELFARE: AN UPDATE 7 (The Casey-CSSP Alliance for Racial Equity in the Child Welfare System 2006).

5. U.S. Census (2000); THE AdOPTION AND Foster CARE ANALYSIS AND REPORTING SYSTEM (2000) (“AFCARS").

6. Hill, supra note 4, at 1.

7. Susan Dougherty, PRactices that Mitigate the EFFECTS of RaCial/ETHNiC DisPROPORTIONALITY IN THE CHILD WELFARE SYSTEM 27 (2003), available at http://www.casey.org/Resources/Archive/Publications/MitigatingDisproportionality.htm. 
experience the legal system when abuse and neglect are at issue. I argue that the law must change in order to counterbalance the existing racial disparities in a large-scale, meaningful way so as to provide equal protection to AfricanAmerican families and children.

My proposal for legal redress of disproportionality for African-American children in the child welfare system is the African-American Child Welfare Act. This federal legislative act addresses the disparities identified at each decision point for children who come under the microscope of the child welfare system. While there are practices and policies that must be changed within state agencies and service providers, there is a significant history in the United States linking equal outcomes with laws that mandate equal treatment and consideration for all races. Although federal laws now provide for equal access and allow integration of the races, there is still an ongoing struggle to battle stereotypes, assumptions, and ignorance that African-Americans regularly face. The dogma that supported four centuries of chattel slavery has proven to be a continuing presence that affects major facets of life for many AfricanAmericans. In fact, there is evidence showing that covert racism and discrimination are still very much in effect. ${ }^{8}$ Therefore, in order for radical change in institutional policies and subjective decision-making to take place, a change in the law is essential.

The first part of the article presents an overview of disproportionality by presenting the national statistics and research, thus revealing where racial bias and disparate treatment occurs within the child welfare system. Current state legislation developed to address disproportionality will also be discussed. The second part of the article outlines the legislative act and sets forth proposed goals for the both the legal and social work systems that serve to protect children and improve family relationships. It will also examine the need for federal legislation to address the problem of over-representation of AfricanAmerican children in the foster care system. The third part of the article analyzes the constitutional issues that arise when proposing a federal law with different legal guidelines for one race. I conclude stating that the AfricanAmerican Child Welfare Act (AACWA2) ${ }^{9}$ passes the strict scrutiny test since maintaining African-American families is a compelling government interest. Furthermore, AACWA2 is narrowly tailored to address the remedial purpose of reducing the proportion of African-American children that enter and remain in foster care. AACWA2 provides a distinct due process procedure in order to

8. John C. Duncan, Jr., The American 'Legal' Dilemma: Colorblind I/Colorblind II - The Rules Have Changed Again: A Semantic Apothegmatic Permutation, 7 VA. J. SOC. POL'Y \& L. 315, 349-50; Roberts, supra note 2 at 230-31; Roy L. Brooks, Race as an Under-Inclusive and Over-Inclusive Concept, 1 AFR.-AM. L. \& POL'Y REP. 9, 18 (1994).

9. AACWA is the acronym commonly used to identify the Adoption Assistance and Child Welfare Act of 1980. Since the initials of the African-American Child Welfare Act are the same, I am using the acronym AACWA2. 
eliminate the disparate treatment that African-American children and families encounter in the child welfare system.

\section{OVERVIEW OF DISPROPORTIONALITY IN THE CHILD WELFARE SYSTEM}

\section{A. National Statistics and Research}

Research on disproportionality in the child welfare system is growing because people can no longer ignore the impact of race on outcomes in the system. Race is a significant factor that determines what happens to children and families of color who encounter child protection services. ${ }^{10}$ The longstanding problem of racial inequities is said to be "of such urgency that no lasting improvements are possible in child welfare services unless these inequities are reduced and eventually eliminated." "The Pew Commission on Children in Foster Care recognized the problem in 2004, and the United States Government Accountability Office (GAO) recently reported on this issue in July of $2007 .^{12}$ The GAO was asked to analyze: (1) the major factors influencing the proportion of African-American children in foster care, (2) the extent that states and localities have implemented promising strategies, and (3) ways in which federal policies may have influenced African-American representation in foster care. ${ }^{13}$ The Casey Alliance for Racial Equity which consists of the five Casey sister organizations has developed and implemented a multi-year, national campaign to reduce the disproportionate number of youth of color in foster care and improve their outcomes. Of the half million children living in foster care placements in 2003 , over $59 \%$ were children of color even though they represented only $41 \%$ of the country's child population. ${ }^{14}$ AfricanAmericans and American Indians are the two most overrepresented groups, represented in foster care at twice their proportions in the census population. ${ }^{15}$

The Indian Child Welfare Act of 1978 (ICWA) $^{16}$ is a federal law

10. The Center for Community Partnerships in Child Welfare of the Center for the Study of Social Policy, Places to Watch - Promising Practices to Address Racial Disproportionality in

Child Welfare, 7 (2006), available at http://www.cssp.org/uploadFiles/Promising_Practices_to_Address_Racial_Disproportionality.pdf.

11. Id.

12. The PEW COMMISSion on ChILdREN In Foster Care, Fostering the Future: SAFETY, PERMANENCE AND Well-BeING FOR CHILDREN IN FOSTER CARE ( 2004); U.S. GOVERNMENT ACCOUNTABILITY OFFICE -07-816, AFRICAN AMERICAN CHILDREN IN FOSTER CARE, REPORT TO THE CHAIRMAN, COMMTTEE ON WAYS aND MEANS, HOUSE OF REPRESENTATIVES (2007), available at http://www.gao.gov/new. items/d07816.pdf.).

13. GAO 07-816, supra note 12 , at 1 .

14. CASEY Family Programs, Disproportionality IN THE ChILd WELFare SySTEM 1 (2006).

15. Hill, supra note 4 , at 15.

16. 25 U.S.C. $\S \S 1901-1963$ (1997). 
addressing the issue of disproportionality for Native Americans within the child welfare system. ICWA provides a due process procedure by which American Indian tribes have exclusive authority to make the decisions concerning abused or neglected Native American children. ${ }^{17}$ There is a higher burden of proof for Native American children to be removed from their parents requiring clear and convincing evidence and testimony from an expert witness for a court to make any findings of abuse or neglect. ${ }^{18}$ If a Native American child is removed from his parents, efforts must be made to place the child with relatives or a foster family from the child's specific American Indian tribe. ${ }^{19}$ This law was the result of congressional findings that the United States government, through the Bureau of Indian Affairs, had removed large numbers of Native American children from their parents based on allegations of neglect and placed the majority of these children with white families who eventually adopted them. ${ }^{20}$ In 1978, more than $17 \%$ of school-age Native American children lived in Bureau of Indian Affairs' institutional facilities or homes, and one out of every four Native American children under the age of one had been adopted. ${ }^{21}$ The figures for displaced African-American children are almost as high as those figures reported for Native American children in the 1970s. ${ }^{22}$ Though ICWA addresses disproportionality for Native American children, there is no federal legislation doing the same for African-American children.

The Synthesis of Research on Disproportionality in Child Welfare: An Update by Dr. Robert B. Hill provides one of the most recent examinations of the issue. When exploring the causes of disproportionality, theories about family risk factors, community risk factors, and systemic factors are all supported by various social work and legal professionals. ${ }^{23}$ However, it is clear from various research projects conducted in different states around the country that disparity exists at several stages throughout African-American families' encounters with Child Protective Services (CPS), including decision points, treatment, services, and resource availability. ${ }^{24}$

In December 2006, the Center for Community Partnerships in Child

17. 25 U.S.C. $\S 1911$.

18. 25 U.S.C. $\$ \S 1912,1921$.

19. 25 U.S.C. \& 1915.

20. Barbara Ann Atwood, Flashpoints Under the Indian Child Welfare Act: Toward a New Understanding of State Court Resistance, 5 EMORY L.J. 587, 601-05 (2002).

21. Cynthia G. Hawkins-Leon, The Indian Child Welfare Act and the African American Tribe: Facing the Adoption Crisis, 36 BRANDEIS J. FAM. L. 201, 201-02 (1997).

22. Id. at 213 .

23. Hill, supra note 4, at 8 (citing J. McCrory, S. Ayers-Lopez, \& D. Green, Disproportionality in Child Welfare, 12 PROTECTION CONNECTION 1-16 (2006)); National Association of Public Child Welfare Administrators, Disproportionate Representation in the Child Welfare System: Emerging Promising Practices Survey (2006); U.S. Administration for Children and Families, Children of color in the child welfare system: Perspectives from the child welfare community, U.S. Department of Health and Human Services (2003).

24. Hill, supra note 4, at 3 . 
Welfare, part of the Center for the Study of Social Policy, published Places to Watch, an overview of practices different states use to address racial disproportionality in child welfare. This report reveals that in all states, the race of children and families is a significant factor in determining what happens to children of color at important decision points in the child welfare system. ${ }^{25}$ Once children of color enter foster care, they receive fewer services while in care and reach adulthood less prepared than their Caucasian peers. ${ }^{26}$ Minority children experience more placements and moves, receive fewer support services, have less contact with case workers, stay in the system longer, and are less likely to be adopted or reunited with their families when compared to white children. ${ }^{27}$ A higher percentage of youth of color leave foster care without a high school diploma. ${ }^{28}$ A large number of these children enter the juvenile and adult penal systems, become teenage parents and illegal substance abusers, and many are among the homeless. ${ }^{29}$ It has been clear for some time that the child welfare system has failed foster youth, but this failure disproportionately affects African-American children. ${ }^{30}$

There has been research on whether the rate of abuse and neglect is higher among African-Americans than whites. Three phases of the National Incidence Studies of Child Abuse and Neglect (NIS) conducted in 1980, 1986 and 1993 found that children of color are not abused at higher rates than white children, which comes as a surprise because of the disproportionate number of children of color in the child welfare population. ${ }^{31}$ The NIS methodology identifies a much broader range of children than those who come to the attention of CPS agencies and the even smaller subset of those who subsequently receive child protective services. $^{32}$ The NIS findings suggest that different races receive differential attention somewhere during the process of referral, investigation, and service allocation, and the overrepresentation of these children does not derive from inherent difference in their rates of abuse and neglect. ${ }^{33}$ After controlling for various risk factors, including income and family structure, the Third National Incidence Study of Child Abuse and Neglect - Final Report

25. Y.E. Lu, Race, Ethnicity, and Case Outcomes in Child Protective Services, 26 CHILD AND YOUTH SERVICES REV. 447 (2004).

26. Mark E. Courtney \& Richard P. Barth, Race and Child Welfare Services: Past Research and Future Directions, 75 CHILD WELFARE 99, 99-136 (1996).

27. Id.

28. Id.

29. The Children's Aid Society, Aging Out of Foster Care II, available at http://www.childrensaidsociety.org/files/Foster_Care.pdf.

30. Erik Eckholm, Offering Help for Former Foster Care Youths, N.Y. TIMES, Jan. 27, 2007, at A11.

31. Hill, supra note 4, at 13.

32. Andrea J. Sedlak, Ph.D. \& Diane D. Broadhurst, M.L.A., Third National INCIDENCE STUDY OF CHILD ABUSE AND NEGLEC:FiNAL REPORT (NIS-3), U.S. Department of Health and Human Services, at 4-30 (1996).

33. Id. 
(NIS-3) further found significantly lower rates of maltreatment for Black families relative to white families. ${ }^{34}$ Based on a secondary analysis of the first two NIS data, black communities had lower rates of child maltreatment than white communities once factors such as income level, unemployment rates, and urban or rural settings were statistically controlled. ${ }^{35}$ Although there is an overall finding of no racial differences of abuse rates, this actually reflects the cumulative result of countervailing forces. The lower risk of AfricanAmerican children is obviated in the overall pattern precisely because of the influences of their several disadvantaging characteristics: living in large, single parent families with low income and unemployed parents. ${ }^{36}$ These characteristics all contribute as risk factors, but their effect is to raise the otherwise lower African-American maltreatment rates to approximate the level of white maltreatment rates. ${ }^{37}$

There is debate within the profession as to whether poverty, rather than race, has a greater impact on disproportionality. Nationally, African-American children are nearly three times more likely than whites to live in poverty. ${ }^{38}$ Much of the research sets forth that poverty is a major contributing factor to child abuse and neglect. ${ }^{39}$ Poverty exposes families to multiple stress factors that may compromise their ability to manage day-to-day activities. Though there is a strong association between poverty and child maltreatment, poverty does not cause maltreatment. The effects of poverty do interact with other risk factors such as unemployment, substance abuse, single-headed female households, depression, teenage pregnancy, and domestic abuse to increase the likelihood of maltreatment. Furthermore, the receipt of welfare benefits doubles the risk of substantiation, and when children themselves are on public assistance their chance of entering the system is amplified further. ${ }^{40}$

The United States Supreme Court's rationale in Wyman v. James illustrates the assumptions made about the poor and the way poor people treat their children. ${ }^{41}$ It held that the Fourth Amendment's prohibition of unreasonable searches and seizures was not violated by the termination of a welfare recipient's benefits because she refused to permit her caseworker to make a home visit, even though she was willing to meet with the caseworker outside her home. The majority said a welfare recipient could refuse entry with

34. Hill, supra note 4 , at 13-14.

35. Id. at 14 .

36. Id.

37. Id.

38. ANNIE E. CASEY FOUNDATION, 2007 KIDS COUNT DATA BOOK 52 (2007).

39. GAO 07-816, supra note 12 , at 4.

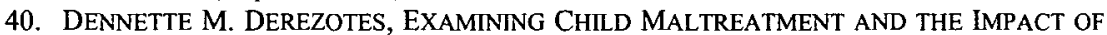
RACE IN RECEIPT OF CHILd WelfaRe SERVICES IN THE UNITEd STATES 16-17 (2003) (citing R.M. GEORGE \& B.J. LEE, THE ENTRY OF CHILDREN FROM THE WELFARE SYSTEM INTO FOSTER CARE: Differences by RaCE (2001), and R.P. BARTH, ChILd Welfare and Race: UNDERSTANDING DISPROPORTIONALITY (2001)).

41. Wyman v. James, 400 U.S. 309 (1971). 
no risk of criminal penalty, just a termination of welfare benefits, and that there were important reasons for such home visits, including detection of child abuse. Justice Thurgood Marshall dissented stating:

Would the majority sanction, in the absence of probable cause, compulsory visits to all American homes for the purpose of discovering child abuse? Or is this Court prepared to hold as a matter of constitutional law that a mother, merely because she is poor, is substantially more likely to injure or exploit her children? Such a categorical approach to an entire class of citizens would be dangerously at odds with the tenets of our democracy. ${ }^{42}$

Even the Supreme Court played a part in shaping the mindset of the American people regarding stereotypes about which children are at risk for child abuse.

\section{B. Where Disparate Treatment and Racial Bias Appear: The Decision Points}

The differential response to children and families of color at important decision points in the child welfare system by professionals is often traced back to racial bias. ${ }^{43}$ Both explicit bias (the stated values which are used to direct behavior deliberately) and implicit bias (those unconscious attitudes) have been shown to impact decision-making among caseworkers employed by state agencies responsible for investigating and monitoring reports of abuse and neglect. Many African-American caseworkers report that white staff lacked exposure to cultures other than their own and had no context for understanding the cultural norms and practices of minority populations. Cultural misunderstanding by juvenile and family court judges also plays a role in the proportion of African-American children entering foster care. ${ }^{44}$ All of these things combine to form structural racism, which both produces and maintains racial inequities in America today. Structural racism identifies aspects of our history and culture that have allowed the privileges associated with "whiteness" and the disadvantages associated with "color" to endure and adapt within the political economy over time. ${ }^{45}$ Structural racism also points out the ways in which public policies, institutional practices and cultural representations reproduce racially inequitable outcomes. ${ }^{46}$

42. Id. at 342 .

43. See GAO 07-816, supra note 12 , at $22-25$; Hill, supra note 4 , at $47-74$.

44. GAO 07-816, supra note 12, at 24.

45. DennetTe M. Derezotes, RaCe Matters: EfFectiveness of Services to AFRICAN-AMERICAN FAMILIES AND CHILDREN 14 (2006).

46. Id. 


\section{Reporting}

Incidents of child abuse and neglect are primarily reported by persons who are legally mandated to do so. The top four sources of reports to CPS hotlines in 2005 were educational staff, law enforcement officials, social service employees, and medical personnel. ${ }^{47}$ Studies have shown that less than $50 \%$ of reportable child maltreatment situations are actually reported, and there may be racial and economic differences in who reports, who gets reported, and the types of maltreatment that are reported. ${ }^{48}$ In a recent study, the differential treatment of African-Americans as a result of discriminatory practices within the larger society manifested itself most often in the overreporting of child abuse and neglect of minority children. ${ }^{49}$

Research also shows that both public and private hospitals overreport abuse and neglect among blacks and underreport maltreatment among whites. ${ }^{50}$ A study done by pediatricians in 2002 revealed that reports of suspected abuse of children with pediatric fractures were filed for $23 \%$ of white children and $53 \%$ of minority children. ${ }^{51}$ This study further revealed that minority children ages twelve months to three years were significantly more likely to have a skeletal survey performed compared with their white counterparts, even after controlling for insurance status and likelihood of abuse. The doctors found that racial differences do exist in the evaluation and reporting of pediatric fractures for child abuse, particularly in toddlers with accidental injuries.

Other research indicates that Black women are more likely than white women to be reported for child abuse when their newborns tested positive for drug use. ${ }^{52}$ Participants in a study in Illinois, Virginia and Texas felt that doctors and other health care providers tended to believe drug use was more common among minority groups. ${ }^{53}$ As a result, medical personnel were more likely to suspect and report minority families for drug use during pregnancy. In many instances, African-American pregnant women are routinely tested for illegal drugs in their system without the mother's knowledge or consent. ${ }^{54}$ This issue has tremendous bearing on racial disproportionality in the child welfare

47. U.S. DEPARTMENT OF HEALTH AND Human SERVICES, ChILd MALTREATMENT 2005 6-7 (2007).

48. Alice M. Hines, Factors Related to the Disproportionate Involvement of Children of Color in the Child Welfare System: A Review and Emerging Themes, 26 CHILDREN AND YOUTH SERVICES REV. 516, 516 (2004).

49. U.S. DePartment OF Health and human SERVICES, ChILdREN OF COLOR IN THE ChILD Welfare SYSTEM: PersPeCtives From THE CHILd WELFARE COMMUNITY 23 (2003).

50. Hill, supra note 4, at 18 .

51. Lane, Racial Differences in the Evaluation of Pediatric Fractures for Physical Abuse, 288 J. OF THE AM. MEDICAL ASSOC. 1603, 1605-1609 (2002).

52. Id.

53. U.S. DEPARTMENT OF HEAL.TH AND HUMAN SERVICES, supra note 48.

54. Id. at 24 . 
system, given that drug abuse is currently one of the major reasons for child welfare involvement with families. ${ }^{55}$

School personnel overreport minority children for neglect as well and frequently confuse neglect with issues related to poverty, calling in neglect reports regarding children who were hungry, unkempt, or sometimes absent or late for school. ${ }^{56}$ Social workers stated in one study that teachers report children who come to school dirty or whose clothes are always dirty, when the reason for this situation is that some minority families don't have a washer and dryer or don't have the money to go to the laundromat daily. ${ }^{57}$ These types of poverty issues have nothing to do with child abuse and neglect, but result in a higher number of African-American children and families being referred to the state for child maltreatment.

\section{Investigation}

The decision of whether to investigate a report of child abuse and neglect is one of the first determinations made in a child welfare case. AfricanAmericans were found to be investigated twice as often as Caucasians in a 2000 study using data from the National Child Abuse and Neglect Data System (NCANDS) ${ }^{58}$ Several studies have found race alone or race interacting with other factors is strongly related to the rate of investigations. ${ }^{59}$ One study revealed that Black families were more likely to be screened in for neglect and physical abuse investigations, while white families were more likely to be screened in for sexual abuse investigation. ${ }^{60}$ Another study revealed that African-American families are more likely to be investigated when reports come from mental health or social service agencies, whereas Caucasian families are at a higher risk of investigation if the parents are not in the workforce or if the perpetrator is not a parent or parent-substitute. ${ }^{61}$

\section{Substantiation of Abuse or Neglect}

If the investigation results in a substantiated finding of abuse or neglect, the next decision to be made is whether the child should be removed from the home. In a review of studies on the substantiation of child maltreatment

55. Susan J. Kelley, Child Maltreatment in the Context of Substance Abuse, in THE APSAC HANDBOOK ON CHILd MALTREATMENT 105, 106 (John E.B. Myers, et al., 2d ed. 2002).

56. Id.

57. Id.

58. Yaun J. Fluke, J. Hedderson \& P. Curtis, Disproportionate Representation of Race and Ethnicity in Child Maltreatment: Investigation and Victimization, 25 CHILDREN AND YOUTH SERVICES REV. 359 (2003).

59. Hill, supra note 4 , at 19-20.

60. Hill, supra note 4, at 19.

61. Derezotes, supra note 44 , at 16. 
reports, the race or ethnicity of the victim or family was one of four key predictors for this decision. ${ }^{62}$ Substantiation was more likely when reports were made by professionals, when there had been prior reports of abuse or neglect, when the report was for physical abuse, and when the family was Black or Hispanic. Studies in Minnesota found reports of maltreatment for Black families were over six times more likely to be substantiated than white reports. ${ }^{63}$ In Illinois, Black reports were more likely to be substantiated than white reports, and for physical abuse reports in New York, race was the only demographic characteristic having an effect on substantiation rates. ${ }^{64} \mathrm{~A}$ frequently cited example of social worker bias is the difference in perception between white and Black workers regarding what constitutes abuse and discipline, particularly within African-American culture. ${ }^{65}$ Other studies revealed that factors like welfare benefits, family structure, and parental education interacted with race resulting in more allegations being substantiated for Black children than white children. ${ }^{66}$

\section{Removal and Placement in Foster Care}

The 2003 National Child Abuse and Neglect Data System (NCANDS) found that African-American children who were determined to be victims of child abuse and neglect were $36 \%$ more likely than Caucasian children to be placed into foster care. ${ }^{67}$ Prior child welfare history and the mother's race were the strongest predictors of foster care placement of children. The children who were more likely to receive in-home services had the following advantaging characteristics: (a) they were older when they entered the system; (b) lived in two parent families; (c) had at least one employed parent; (d) neither parent abused drugs; (e) their family relied on earnings and not Aid to Families with Dependent Children (AFDC); (f) lived in low crime neighborhoods; and (g) had no prior CPS history. ${ }^{68}$ Racial comparisons reveal that Black children were less likely than white children to have these advantaged characteristics. Moreover, even when Black children did have these characteristics, they were still more likely to be placed in foster care than comparable white children. ${ }^{69}$

62. Hill, supra note 4, at 20.

63. Id.

64. Hill, supra note 4 , at 20-21.

65. Susan Chibnall et al., U.S. ChILdRen's Bureau, ChILdRen of COlor IN THE CHILD WELFARE SYSTEM : PERSPECTIVES FROM THE CHILD WELFARE COMMUNITY 10 (2003), available at http://www.childwelfare.gov/pubs/otherpubs/children/children.pdf.

66. Richard Barth, Child welfare and race: Models of disproportionality, in RACE MATTERS IN CHILD WELFARE: THE OVERREPRESENTATION OF AFRICAN-AMERICAN CHILDREN IN THE SYSTEM, 25, 25-46 (Dennette Derezotes et al. eds., 2005).

67. U.S. Department of Health and Human Services, Child Maltreatment (2005), available at http://www.acf.hhs.gov/programs $/ \mathrm{cb} /$ pubs $/ \mathrm{cm} 05 / \mathrm{cm} 05$.pdf.

68. Hill, supra note 4, at 21-22.

69. Id. at 22 . 
Other factors that affect African-American children's higher entry into foster care include lack of affordable housing options, lack of access to substance abuse treatment, and the limited or inadequate legal representation of birth parents. ${ }^{70}$ Affordable public housing is a critical support that can help low-income families stay together and allow for in-home services, decreasing the chances of children being removed from their home. A higher percentage of African-American families live in impoverished neighborhoods that lack resources like public housing, drug treatment services, and job training. ${ }^{71}$ In at least twenty states, African-American families have difficulty obtaining adequate legal representation in court which contributes to their disproportionate numbers in foster care. Public attorneys assigned to lowincome parents often do not meet parents before they appear in court and have little time to review case files, putting parents at a disadvantage in the legal setting. ${ }^{72}$ This inadequate representation fuels African-American parents' distrust of the child welfare system and their belief that racial bias affects caseworker decisions and judicial rulings. The distrust stems from their perception that the system is unresponsive to their needs and racially biased against them. Many see caseworkers as more intent on separating AfricanAmerican parents from their children than on working within their communities to address child safety issues. In twenty-eight states, to a moderate extent, African-American families' distrust of the child welfare system was a factor contributing to the entry of African-American children into foster care. ${ }^{73}$

\section{Provision of Remedial Services}

Once children and families enter child welfare systems, there is evidence that indicates differential treatment with regard to services provided, both in terms of quantity and quality. ${ }^{74}$ In a study of social workers, many participants felt their colleagues, across racial and ethnic groups and job categories, brought preconceived ideas or biases against minority groups, most often AfricanAmericans, to their position. ${ }^{75}$ The study revealed that Caucasian staff in particular lacked exposure to cultures other than their own and had no context for understanding the cultural norms and practices of minority populations. ${ }^{76}$ Focus groups indicated that caseworkers often judge families from their own standards of appropriate behavior, rather than thoroughly assessing risk and

70. GAO-07-816, supra note 12 , at 20.

71. Id. at 21 .

72. Id. at 22 .

73. Id. at $22-23$.

74. Veronica D. Abney, Cultural Competency in the Field of Maltreatment, in THE APSAC HANDBOOK ON CHILD MALTREATMENT 477, 480 (JOHN E.B. MYERS, ET AL., 2D ED. 2002).

75. CHIBNALL et al., supra note 64 , at 26.

76. Id. 
considering families' culture in the assessment process. ${ }^{77}$

\section{Exits from Foster Care}

Slower rates of exits from foster care also contribute to the disproportionality of minority children. A Congressional Research Service study found that white children exiting care in 2003 were more likely to be reunified with their families than Black children. ${ }^{78}$ National data from 2005 reveals that white children were four times more likely to be reunified than Black children. $^{79}$ In most cases, African-American children had lower probabilities of being adopted than white children, and adoption finalizations for Black children took longer than for white children. Certain factors made finding permanent homes for African-American children more challenging, which contributed to longer stays in foster care. These factors include a lack of appropriate adoptive homes, difficulties in finding adoptive families for older African-American children, and the belief that African-American children are more likely to have special needs,

\section{Current State Legislation Addressing Disproportionality}

State government involvement is important for the same reasons the proposed federal legislative act outlined in this article is important. Several states have researched disproportionality in the child welfare system and collected insightful information as to the reasons behind the increased numbers of children of color entering and remaining in state custody. California, Iowa, Michigan, Illinois, Washington, Texas, North Carolina, Minnesota, Tennessee and Connecticut are all states that have expended time and effort to determine why the issue exists in their states. There are seven states that have created commissions or separate departments through legislative acts or governor's executive orders so that funding could be secured for research as well as any recommendations from the research. ${ }^{81}$ Florida, Illinois, Iowa, Michigan, Minnesota, Texas and Washington are the states that currently have legislation that addressing African-American disproportionality in the child welfare system. ${ }^{82}$

The Illinois state legislature passed the Illinois African-American Family Commission Act in $2004{ }^{83}$ It is the culmination of over ten years of work

77. $I d$.

78. Hill, supra note 4, at 24.

79. Id.

80. GAO-07-816, supra note 12, at 25 .

81. Alan J. Dettlaff, Ph.D. \& Joan R. Rycraft, Ph.D., Region 3 Focus Groups on Disproportionality - Final Report 15-16 (2007) (on file with author).

82. Id. at 15 .

83. Illinois African-American Family Commission Act, 2004 Ill. Laws SB 3208, PA 930867. 
started by members of the African-American Family Policy and Family Preservation Task Force, which eventually led to the creation of the AfricanAmerican Family Commission in 1994. This Illinois Act provided comprehensive findings regarding the disparities of African-Americans in education, employment, income, and health, and connected these disparities to the challenges facing African-American families in Illinois. The Illinois Act seeks to promote family preservation and strengthen families. ${ }^{84}$ In 2000, African-American children comprised $73 \%$ of the children in substitute care but only $18 \%$ of children in Illinois. ${ }^{85}$ The Illinois African-American Family Commission Act expands the role of the Commission from being focused solely on developing and implementing programs and public policies that affect the state's child welfare system to encompass working relationships with every department, agency, and commission within state government if its activities impact African-American children and families. The Illinois Act recognizes broader issues of health, mental health, criminal justice, education, and economic development directly affecting the health and well-being of AfricanAmerican families and children.

In 2005, Michigan passed Act No. 147 which was an act to make appropriations for the Department of Human Services and certain state goals related to public welfare services. ${ }^{86}$ Part of this act included the creation of a task force to study the disproportionate representation of African-American children and other children of color in the child welfare and juvenile justice systems of the state. The task force was mandated to report the results of the study and to make administrative and legislative recommendations for appropriate program services to reduce existing disparities and bias in the systems and improve the long-term outcomes for children. ${ }^{87}$

Since the bill's passage, the 2006 report from the Michigan Advisory Committee on the overrepresentation of children of color in child welfare revealed commonalities found across many states--African-American children were more likely to be under state supervision and generally fared worse than other foster children. ${ }^{88}$ It also found that overrepresentation in the protective services system helped to feed disparities in the juvenile justice system; there was a "slippery slope" leading from children's protective services to juvenile detention and sometimes prison. ${ }^{89}$ There were eleven recommendations that came from Michigan's blueprint for change. The majority of them included collaborative processes between the state and local policymakers, public and

84. Id. at $\S 5$.

85. $I$ ld.

86. 2005 Mich. Pub. Acts, SB 271.

87. Id. at $\S 548(3)$.

88. MICH. ADVISORY COMM. ON THE OVERREPRESENTATION OF CHILDREN OF COLOR IN CHILD WELFARE, EQUITY- MOVING TOWARD BETTER OUTCOMES FOR ALL OF MICHIGAN'S CHILDREN, 3 (2006).

89. Id. at 3,8 . 
private frontline social workers, law enforcement, prosecutors, courts, community mental health professionals, faith-based organizations, AfricanAmerican community leaders, parents, and youth. ${ }^{90}$ The Michigan Department of Human Services is now improving support for relative caregivers, using early intervention to prevent foster placement, training staff on cultural differences, and strengthening efforts to give families a voice in the services they receive.

In 2005 the Texas Legislature passed Senate Bill 6, which requires the state to take specific actions to address disproportionality. ${ }^{91}$ Findings of disparate outcomes for African-American children in the child welfare system from a 2003 legislative mandate and testimony from the Assistant Commissioner for Child Protective Services prompted policymakers to enact a bill geared toward evaluation and remediation. ${ }^{92}$ Data collected in 2003 showed that African-American children were almost twice as likely to be the subject of a child abuse or neglect report, disproportionately represented in the substantiation stage of investigations, and two and a half times more likely to be removed. ${ }^{93}$ Senate Bill 6 mandates provision of cultural competency to all service delivery staff; targets recruitment efforts to ensure diversity among state department staff; increases targeted recruitment for foster and adoptive parents to meet the needs or children waiting for homes; requires an analysis of disproportionality to determine why disparities exist; further requires the development and implementation of a remediation plan; and provides funding for evidence-based programs in the community to prevent child abuse. ${ }^{94}$

The state of Washington followed behind Texas and put into law Substitute House Bill 1472 in 2007.95 This bill included Native American children, who are overrepresented in foster care in the Washington child welfare system. In 2005, King County, Washington completed a quantitative and qualitative report on racial disproportionality data. ${ }^{96}$ The state utilized this data to set forth specific findings and to establish an advisory committee charged with analysis of the issue and development of a remediation plan. Many of the strategies employed involved collaborative efforts of state child welfare agencies, community leaders, attorneys, judges, and policymakers. In Washington, three projects were designed to impact disproportionality: (1)

90. Id. at $18-22$.

91. 2005 Tex. Gen. Laws SB 6, Chap. 268, Sec. 1.54.

92. 2004 Tex. Exec. Order RP 35 (2004); Deborah K. Green, DEP'T OF FAMILY AND Protective Services, Child Protective Services Div., Breakthrough Series COLLABORATIVE APPLICATION - AGENCY AND COMMUNITY READINESS 4 (2005).

93. Green, supra note 91 , at 4.

94. Tex. Gen. Laws, supra note 90.

95. 2007 Wash. Sess. Laws HB 1472, Chap. 465.

96. King County Coalition on Racial Disproportionality, Racial Disproportionality in the Child Welfare System in King County, Washington, Report: Quantitative and Qualitative Data on Racial Disproportionality (2004), available at http://www.chs-wa.org/KingCountyReportonRacialDisproportionality.pdf 
King County Systems Integration Initiative; (2) The Benchmark Hearings Pilot Project; and (3) Champions for Permanence Project. ${ }^{97}$ The first project was developed to reform the culture, policies, practices, programs and protocols that are currently being used in the judicial and child welfare systems so that there is more information sharing and cross-systems training. ${ }^{98}$ The latter two focus on decreasing the number of children who have been in foster care longer than two years, specifically targeting African-American and Native American children. ${ }^{99}$

Places to Watch, an overview of practices developed in different states to address racial disproportionality in child welfare, highlights the mostly social service and educational methods put into place to address racial inequities in the child welfare system. ${ }^{100}$ Many of the states have extensive collaborations between the private and public sectors, along with data collecting mechanisms to document the progress of the strategies. Few of the programs utilized lawyers or the court system directly or required any cultural competency training of the judges or attorneys who work with African-American families and children. For example, Illinois offered forums to educate policymakers, advocates, and politicians about public policies affecting the quality of life of African-American families in the state. ${ }^{101}$ Minnesota mandated that juvenile courts ensure that reasonable efforts be made for culturally appropriate services to prevent placement or to eliminate the need for removal of children of color from their homes. ${ }^{102}$ North Carolina has a small fund to help kinship caregivers purchase legal services to establish custody in order to prevent children from unnecessary placement in the child welfare system. ${ }^{103}$ These efforts made by the ten states cited in Places to Watch are a great beginning to what should be a national movement towards eliminating racial disproportionality in the child welfare system. While each state can create tailor-made solutions for the issue of disproportionality of African-American children in the child welfare system, this manner of addressing the problem is slow to establish change across the entire country. In order to achieve more comprehensive results, a federal law should be passed to address a problem that increasingly has negative outcomes for African-American children and families across our country.

97. The Center for Community Partnerships in Child Welfare, supra note 10, at 67.

98. Id.

99. Id.

100. The Center for Community Partnerships in Child Welfare, supra note 10, at 64 .

101. Id. at 17.

102. Id. at 33-34

103. Id. at 52 . 


\section{THE AFRICAN-AMERICAN CHILD WELFARE ACT}

\section{A. Outline of Federal Legislation}

I propose federal legislation to address the issue of disproportionality of African-American children in the child welfare system. The African-American Child Welfare Act ("AACWA2") is a creative bill that has not been presented to or by any member of Congress. AACWA2 would be comprised of three sections. The first will focus on the child protection system. The second section would deal with the education system within the juvenile delinquency system, and the third section would address the problems for African-American children stemming from the medical and health care systems of the United States. Though the focus of this act would be the children, it would also provide assistance, both financial and educational, to the parents and relative support network who may share custodial responsibility for the children. ${ }^{104}$ The second and third sections will be addressed through two subsequent articles.

\section{Legal Burden of Proof}

Most child protection cases begin in the legal system with a substantiated referral of child abuse or neglect which is put in the form of an affidavit after a short, intense investigation. A judge reviews the petition and the supporting affidavit and then makes a determination as to whether the child should be removed from the parents' custody. The legal burden of proof initially is fairly easy to reach, and it changes depending on what stage the case is in. In Texas, for example, there are as many as three different burdens of proof for CPS cases. ${ }^{105}$ Throughout the fifty states, there is no consistent burden of proof standard for removal of a child from a parent's care; it varies from preponderance of the evidence to clear and convincing evidence. ${ }^{106}$ Though this legal burden sets up a standard by which attorneys must present evidence,

104. See Jessica E. Marcus, The Neglectful Parens Partriae: Using Child Protective Laws to Defend the Safety Net, 30 N.Y.U. REV. L. \& Soc. CHANGE 255, 260 (2006). Marcus argues that when the state assumes parental responsibility for children, it has an affirmative obligation to provide poor parents with the resources necessary to meet minimum standards. See also Jane C. Murphy, Protecting Children by Preserving Parenthood, 14 WM. \& MARY BILL RTS. J. 969, 973 (2006). This article examines legal recognition of mothers under child abuse and neglect law. Murphy argues that current policy acts to deprive poor children of birthmothers without providing a mother-substitute.

105. The burden of proof on initial removal is similar to preponderance of the evidence. Technically, it is "sufficient evidence necessary to satisfy a person of ordinary prudence and caution that there is a continuing danger to the physical health or safety of the child and for the child to remain in the home is contrary to the welfare of the child . . ... Tex. Fam. Code $\S$ 262.201 (c). The burden of proof on a termination petition is clear and convincing evidence. Tex. Fam. Code $\S 161.001$.

106. Child Maltreatment 2005, supra note 66, at 123-62. 
it does not take into account any cultural bias or underlying assumption made on the basis of ethnicity of the family or their community.

The suggestions of most scholars who have evaluated the problem of disproportionality in the foster care system focus on necessary social welfare changes with very few suggestions to enhance the opportunity of the court to be the check and balance in the system. ${ }^{107}$ In fact, the court was designed to be the objective eyes of the state with regard to removal and placement of children who have been abused and neglected. Children do not enter foster care without a judge entering an order for them to be removed from their families. The judge and the child's attorney, guardian ad litem, or court appointed special advocate (CASA) volunteer are usually the people that are on the legal case from beginning to end. It makes sense for the judge on the case, as the initial fact finder regarding the likelihood that abuse or neglect occurred, to share in the responsibility of assessing whether the parents were dealt with by the state agency in a fair and equitable manner.

The burden of proof for the state is the first issue that would need to change in order for the judge to hear enough evidence to ensure that Black children and their families have been treated in a non-discriminatory manner. Similar to the Indian Child Welfare Act (ICWA), the burden of proof for removal of an African-American child should be higher than preponderance of the evidence. AACWA2 would raise the burden of proof from preponderance of the evidence to clear and convincing evidence at the first hearing for all cases involving African-American children. A different standard for removal has been suggested by numerous scholars to improve the outcome for children in the child welfare system. Law Professor Theo Liebmann argues that initial removal standards should be changed and that comprehensive risk standards should be utilized by social service professionals in order to determine if the risks to a child with their parents are actually greater than the risks to the child's life or health if removed from their parents. ${ }^{108}$ Professor Cassandra Bullock argues for a clear and convincing standard at the initial hearing in order to protect indigent parents' rights to raise their children. ${ }^{109}$ The theory behind changing the removal requirements is that if it becomes more difficult for the state agency to remove an African-American child, there will be more thorough investigations and subsequently more thorough risk assessments. A change in the law would require a change in policy, practice and procedure for state agencies responsible for investigating child abuse and neglect.

107. See, e.g., Dougherty, supra note 7 at 3-19.

108. Theo Liebmann, What's Missing From Foster Care Reform? The Need for Comprehensive, Realistic, and Compassionate Removal Standards, 28 HAMLINE J. PUB. L. \& POL'Y 141, 148 (2006).

109. Candra Bullock, Low-Income Parents Victimized by Child Protective Services, 11 AMER. J. GENDER, SOCIAL POL'Y \& THE LAW 1023, 1052 (2003). 


\section{Risk Assessment Screen for Racial Bias}

A concern with this heightened burden of proof standard is that the intention of the law may not be realized. Rather than increasing the likelihood for more thorough investigations, the new burden could cause investigative workers to fail to remove children who are at risk for fear that the evidence collected would not meet the burden of proof. In order to avoid this unintended outcome there could be a screening requirement within the state agency for racial bias, assumptions based on stereotypes, and prejudices. This screening would be completed by the caseworker and reviewed by the supervisor prior to removal. If the supervisor found that the caseworker exhibited some type of bias based on race, an additional assessment would be completed by the investigative caseworker that could account for any point in the decision making where their subjectivity may be in question. This additional task on the part of the caseworker requires the state to incorporate cultural sensitivity or competency training, and not only train caseworkers, but ensure that they utilize the training in their day-to-day interactions with African-American families.

\section{Additional Evidentiary Support for Removal}

The third factor to be addressed in AACWA2 is specified grounds for removal of an African-American child requiring additional evidentiary support. For example, removal could not be based on a positive drug test at birth alone; there must be other corroborating circumstances that warrant the removal of a child. The influx of children with substance abusing mothers into the child welfare system has greatly strained its capacities and resources. ${ }^{110}$ Maternal illegal drug use has caused "too many children [to be] placed in foster care for too long a time with too many successive caretakers." 111 The funding for drug treatment services for women who have children and are pregnant are woefully inadequate when compared to the need for treatment services. ${ }^{112}$ Under AACWA2, the state would need to show that the mother was unable or unwilling to enter a substance treatment program that would allow her child to remain in her custody or that the mother is a flight risk (likely to abscond with the child). The mother must present evidence that she would be able and willing to provide the child with a safe and stable home at the time of release from the substance treatment program. It would be in the court's discretion to appoint a relative as temporary joint custodian until it could be determined if the child could be left permanently in the mother's care. The premise behind requiring this additional evidence is to change the focus of intervention from

110. Josephine Gittler, The American Drug War, Maternal Substance Abuse and Child Protection: A Commentary, 7 J. GENDER RACE \& JUST. 237, 250-51 (2003).

111. Id. at 251 .

112. Id. at 257 . 
punishment to prevention and treatment of illegal drug use and abuse.

Another example might include an alternative of community wrap-around services. For example, if there was a removal based on neglect only (with no drug use), and the parent is under the age of twenty, the court may consider an alternative option of sending the parent and child through a Community Wraparound Program. The parent would be assigned a parenting coach, receive educational or vocational opportunities, and assistance with temporary housing. Increasing the amount of public housing would be the key for this legislation to work properly because a parent's inability to provide adequate shelter greatly reduces the state's option to maintain an intact family.

\section{Mandatory Establishment of Paternity}

The fourth factor of AACWA2 involves an often overlooked party in child protection cases-the fathers. AACWA2 provides that the fathers of each African-American child must be identified, located, and given the opportunity through pro bono legal services to legalize his relationship with his child within the first four months after removal. The U.S. Department of Health and Human Services issued a report entitled, What About the Dads? Child Welfare Agencies' Efforts to Identify, Locate, and Involve Nonresident Fathers. ${ }^{113}$ The report focuses on examining the current policies and practices within the child welfare system to identify, locate and engage fathers from place to place. Child and Family Service Reviews (CFSRs) from twenty-two states revealed a lack of paternal involvement in the case planning process. Focus groups with the caseworkers revealed several key factors: (1) caseworkers felt that fathers were generally at the margins of the child welfare system and often view the agency with distrust, especially if they have a criminal record; (2) caseworkers were less likely to initiate father involvement with families involving multiple fathers; and (3) caseworkers felt that many fathers have little commitment to their children. ${ }^{114}$ Caseworkers also reported that only $29 \%$ of alleged fathers had been located at case opening as compared to $62 \%$ of legal fathers. ${ }^{115}$ Furthermore, cases involving African-American and Hispanic children were associated with decreased odds of having an identified father. ${ }^{116}$

\section{Inclusion of Incarcerated Parents}

The disproportionate number of Black parents in prison is the impetus for

113. K. Malm, J. Murray, and R. Geen, What About the Dads? Child Welfare Agencies' Efforts to Identify, Locate, and Involve Nonresident Fathers, The U.S. Department of Health and Human Services, Office of the Assistant Secretary for Planning and Evaluation (Washington, D.C. 2006), available at http://aspe.hhs.gov/hsp/06/CW-involve-dads/report.pdf.

114. Id at 7-8.

115. Id. at 106 .

116. Id. at 131 
the fifth factor in AACWA2. These high rates of incarceration have an impact on the human resources available within the Black community, and most significantly on the lives of Black children. The incarcerated parents and the immediate relatives of incarcerated parents must be contacted by the state agency within 30 days of removal. Immediate relatives would include grandparents, aunts, and uncles. The state would be obligated to determine parentage and consider any relative the incarcerated parent recommended for their child's placement. Often times these relatives are overlooked or summarily dismissed because the father in prison is not the "legal" father of the child. If parentage were determined, the state could expand the family members that may be willing to care for a child or sibling group.

\section{Early Intervention Methods}

Factor number six would require judges to utilize early intervention methods best suited to their locality (early mediation, family group conferencing, etc.) for every abuse and neglect case concerning AfricanAmerican children. The families involved would be led by a trained mediator or state specialist in order to determine what types of services the parents need, where the child could live temporarily, and how the family and community at large can assist the parents in completing services. Studies have shown that including families in the decision making process and training culturally competent staff would most reduce disproportionality. ${ }^{117}$ In Texas, for example, family group conferencing has led to a reduction in foster care placements and an increase in placements with relatives for all children, with a specific impact on African-American children. Improved outcomes are demonstrated by the fact that $32 \%$ of African-American children whose families attended a family group conference returned home compared to $14 \%$ whose families received traditional services. ${ }^{118}$

\section{Cultural Competence Training}

Mandatory cultural competency training for juvenile court judges and attorneys similar to that provided by the People's Institute for Survival and Beyond's workshop titled Undoing Racism, would be required under the seventh factor. ${ }^{119}$ Education regarding disproportionality and cultural issues must begin in the court system. Lawyers must do their part as advocates of the law to see that the outcome of a law is equitable, and in no way disadvantages one segment of society because of the color of their skin. The way to solve disproportionality and disparity in the child welfare system does not begin or

117. GAO-07-816, supra note 12 , at 36 .

118. Id. at 36 .

119. See People's Institute for Survival and Beyond, Undoing Racism Community Organizing Workshop, available at http://www.pisab.org/about-us/. 
end with a federal legislative act. The community work that has already begun in states around this country is important to changing the way people think. The cultural competency training that has been suggested and sometimes mandated for social service workers has not yet been addressed in the legal arena. The judges and attorneys serving children and parents also need to be educated about different cultures and made aware of the biases that exist in most governmental institutions, and how these biases affect family dynamics.

\section{Funding}

The remainder of the AACWA2 would provide for funding for more support services for relative placements, such as day care, after-school care, clothing and furniture vouchers, affordable family therapy, and initial assistance with supervision of visitation in the home. Funding would also be set aside for non-profits and faith-based initiatives to recruit more AfricanAmerican foster parents and encourage adoption in the African-American community. Each state could have the opportunity to choose the remedy that best fits their locality after having had the benefit of analysis of disproportionality in their region. Funding would also have to be allocated toward maintaining an advisory committee or state commission to study the dynamics of disparity as implementation of the legal and social redress took effect.

\section{Amendments to Adoption and Safe Families Act}

There may need to be amendments made to Adoption and Safe Families Act of 1997 (ASFA) with regard to the one year deadline for permanency. ${ }^{120}$ In certain cases, the court should be able to use its discretion to extend the case at least twice for six month intervals, such that the total time that a child could be in foster care is two years. Though this is not an ideal situation, in specific instances the federal government should allow the state, attorney for the child or parent to show why it is in the child's best interest to extend his or her stay in the foster care system.

\section{B. Why Federal Legislation is Necessary}

\section{Litigation is Not Efficient or Financially Practical to Achieve Change}

Though federal litigation can be used to address the issue of racial disparities within the child welfare system, the African-American Child Welfare Act is the best legal solution for disproportionality. There are many inherent problems with using litigation to carve away at racial disparities. First, litigation is expensive. Most of the families caught in the system are poor and 
unable to afford a lawsuit on their own, requiring the assistance of a nonprofit organization such as the American Civil Liberties Union (ACLU) or National Association for the Advancement of Colored People (NAACP), which are both committed to the goal of dismantling disproportionality through legal channels. Second, race discrimination cases take a long time and may never reach the appellate courts. In many cases, a lawsuit would require an almost perfectly aligned set of circumstances or a series of cases in different jurisdictions to reach review by the Supreme Court. Conversely, since there is such disparity within the child welfare system, it seems that once plaintiffs can get past summary judgment, states are more likely to settle rather than go to trial so as not to reveal all of the potentially damning statistics. There is also no guarantee that a group of plaintiffs could be certified in each state to go forward with a class action case.

Similarly in considering the past litigation efforts to address the underlying issues that cause disproportionality, there have been very few cases where African-American parents or legal guardians have sued child welfare agencies for violating their constitutional rights. In Wilder v. Bernstein, ${ }^{121}$ six children, through their guardians ad litem, filed suit against the New York child care agency and public officials for violating the First, Eighth, and Fourteenth Amendments. The children asserted that the statutory scheme for the provision of child-care services resulted in racial and religious discrimination in access to these services. A settlement was eventually reached after the court held that a cognizable claim of First Amendment violations as well as racial and religious discrimination in violation of equal protection was stated in the complaint. In New York, due to a religious matching preference, the city's child care scheme placed Black children in disproportionately low numbers in Catholic and Jewish agencies, which tended to be the agencies that were better funded and provided higher quality of services. The lawsuit challenged the New York state constitutional and statutory provisions that provided for religious matching based on the parents' preference. The settlement required the city to place children on first come, first-served basis, with a preference for religious matching only to the extent that it does not give a child greater access to a program appropriate for his needs over other children for who earlier became candidates for placement.

In Tina Olison v. Governor George Ryan, ${ }^{122}$ the plaintiff class brought an action against the governor, corrections department, judges, and county alleging racial discrimination and violation of the parent-child relationship, among other claims. The class consisted of African-American families who had children placed in state custody and been denied the equal protections and benefits under the law. The class alleged that African-American children are 
disproportionately placed in foster care and have lower rates of unification with their biological parents as compared to their white counterparts. Though several allegations were made against the defendants, the plaintiffs failed to allege that the state treated the Black parents differently than it treated white parents. All the plaintiffs had pending cases in the state district court. The Fourteenth Amendment claims were dismissed because the court held that it lacked jurisdiction on three grounds: the Eleventh Amendment (deprives federal courts jurisdiction to consider most suits against states), the RookerFeldman Doctrine (federal district courts lack jurisdiction to review decisions of state courts, especially claims "inextricably intertwined" with the state court judgments), and the Younger abstention (absent extraordinary circumstances, a federal court should not interfere with pending state judicial proceedings).

The most recent case, People United for Children, Inc. v. City of New York, resulted in a settlement after almost seven years of litigation. In People United, plaintiffs brought an action under 42 U.S.C. $\S \S 1983$ and 1988 alleging violations of their rights secured by the First, Fourth, Thirteenth, and Fourteenth Amendments to the U.S. Constitution and various provisions of New York's constitution and the Family Court Act. ${ }^{123}$ People United for Children, Inc. (People United) is a non-profit organization that conducts a weekly support group for individuals who have lost custody of their children to the Administration for Children's Services (ACS), the independent agency in charge of the city's child welfare program. Plaintiffs asserted that the state removed children from parents without a reasonable basis to believe that such emergency circumstances existed. Plaintiffs further asserted that they did not need to show that ACS was motivated solely, primarily, or even predominantly by race because it was enough if race was one of several factors for the defendants' actions. The court said that statistics showing the effect of defendants' policies and practices on African-Americans was not enough to establish intentional discrimination. If a neutral law has a disproportionately adverse effect on a racial minority, the Fourteenth Amendment is violated if a discriminatory purpose can be shown. ${ }^{124}$ The Court did acknowledge that the racially disproportionate effect of official action provides an important starting point, but would go no further.

The claim, based on the Fourteenth Amendment's substantive due process and equal protection clauses, involved a three-part test. The court had to (1) examine the nature of interest at stake to determine whether it is a fundamental right protected by the Fourteenth Amendment; (2) determine whether defendants' actions have significantly infringed that fundamental right; and (3) analyze whether an important state interest justifies the infringement. It is beyond dispute that the substantive due process clause protects an individual's 
liberty interest in familial relations, which include a parent's interest in custody of his or her children. ${ }^{125}$ The interest being protected is not only that of parent but also of the children in not being dislocated from the emotional attachments that derive from the intimacy of daily association with the parent. Significant infringement had occurred in People United because plaintiffs' children had been removed from their custody for time periods ranging from one to seven years. The state has an important interest in protecting children from abuse in emergency circumstances, and therefore is justified in depriving plaintiffs of their fundamental liberty interest in cases where there is an objectively reasonable basis for believing an emergency situation exists.

The court rejected the defendants' argument that plaintiffs failed to state a claim under the Equal Protection Clause because they failed to allege that they were treated differently than those who were similarly situated. While plaintiffs do not explicitly state that they were treated differently than similarly situated individuals, they do present statistical evidence of the disparities between African-American and white individuals who come into contact with the foster care system. This evidence implies that plaintiffs were treated differently than other similarly situated individuals. ${ }^{126}$ This case sets a good precedent for future cases because the court did not dismiss the plaintiffs' claims and certified them as a class.

\section{Historically, Racial Disparity Has Required a Revolution of Laws to Force}

\section{Change}

The civil rights achieved for African-Americans through changes in the law from the 1920s through the 1960 s were initiated through lawsuits brought by the National Association for the Advancement of Colored People (NAACP). These lawsuits were carefully chosen by lead attorney Charles H. Houston and attorney (later Supreme Court Justice) Thurgood Marshall to legally challenge racial, economic, social, educational, and political inequalities. "Separate but not Equal" was the slogan of the NAACP as it strove to gain the same opportunities for black children in public schools. Throughout this period, legislation upheld the vestiges of racism and oppression that persisted after passage of the Thirteenth Amendment. Much of the struggle was centered on blacks gaining equal access to jobs, housing, education, public facilities and government services.

African-Americans were not part of the United States child welfare

125. See Stanley v. Illinois, 405 U.S. 645 (1972); See also Gottlieb v. County of Orange, 84 F.3d 511, 514 (2d Cir. 1996).

126. See, e.g., Pisello v. Town of Brookhaven, 933 F. Supp. 202, 211 (E.D.N.Y. 1996) (finding that allegations that plaintiffs were targets of a campaign of prejudicial treatment necessarily implied that other similarly situated enterprises were not subject to the same harassment). 
system until the 1950s, once integration became the law of the land. Racial discrimination and segregation restricted the state's ability to consider black children as victims of child abuse or neglect. It is no coincidence that around the same time that blacks in the U.S. were afforded equal rights in public facilities and agencies, the number of blacks negatively affected by the prison system, welfare system, and child protective system dramatically increased. When the law of the land did not apply to blacks-meaning any injustice could be committed against blacks and go unpunished ${ }^{127}$ - black children were not considered worthy of being saved from abuse or neglect. Black children were not considered full human beings even after the Thirteenth Amendment history and current day scars exist that illustrate that the change in the law did not mean a change in the minds of white Americans. ${ }^{128}$

The only way blacks could achieve equality would be to chip away at these laws and the biased legal interpretation of the U.S. Constitution by the highest court, little by little, case by case. ${ }^{129}$ Victories in the courtroom often produced resistant state agencies that were unwilling to follow the law of the land. By 1950, the NAACP Legal Defense Fund and Thurgood Marshall realized that forcing the mandate of equality on a case-by-case basis would take years and massive funding. Instead, federal legislation became the focus of many people's attention. Legislation to improve the condition of Blacks in the United States became a tool for political candidates to gain votes. It also provided federal agencies with access to funding to distribute services to African-Americans. Congress passed the Civil Rights Act of 1964 as well as several other bills in an effort to provide equal access to Blacks in public accommodations and employment. One of Thurgood Marshall's law clerks, Stephen L. Carter, now a Professor at Yale Law School, stated that the manner in which black attorneys set out to challenge racist laws in the 1950s and 60s was not the way it should always be done-he believed that the great moral battles should be fought in the legislative branch rather than the judicial branch. "The Constitution places some moral choices outside the political process, but

127. STEWART E. TOLNAY AND E.M. BECK, A Festival of ViolencE: AN ANALYSIS OF SOUTHERN LYNCHINGS, 1882-1930 (University of Illinois Press 1992); The American Experience: The Murder of Emmett Till (PBS 2003); PHILIP DRAY, AT THE HANDS OF PERSONS UNKNOWN: THE LYNCHING OF BLACK AMERICA (Random House 2002).

128. Kenneth Clark, $\mathrm{PhD}$, Desegregation: An Appraisal of the Evidence, $9 \mathrm{~J}$. Social Issues 1 (1953).

129. See generally Missouri ex rel. Gaines v. Canada, 305 U.S. 337 (1938) (holding that proposal to provide financial aid so Black student could attend out-of-state law school while denying him admission to in-state, whites-only law school was not equal treatment under the Constitution and violated the Fourteenth Amendment); Smith v. Allwright, 321 U.S. 649 (1944) (primary elections that excluded Blacks were unconstitutional); Morgan v. Virginia, 328 U.S. 373 (1946) (segregated accommodations on interstate buses are illegal); Shelley v. Kraemer, 334 U.S. 1 (1948) (covenants prohibiting Blacks from purchasing homes were unconstitutional); Sweatt $v$. Painter, 339 U.S. 629 (1950) (intangible effects of inequality could violate a plaintiff's right to equal protection under the Fourteenth Amendment); and Brown v. Board of Education, 347U.S. 483 (1954) (overturning separate but equal doctrine and outlawing segregation in public schools). 
most of them are- -and should be-left within it."130

The legacy of racism and discrimination in the United States has not been adequately remedied through current civil rights legislation. In the book, The Future of the Race, Henry Louis Gates, Jr. and Cornel West examine the historical essay written by W.E.B. DuBois, "The Talented Tenth." Gates' response, entitled "Parable of the Talents," sets forth the "Poverty Perplex" of the black poor. Gates asserts that the root cause of poverty is neither a lack of money nor a failure of analysis of the poverty issue, but a failure of national will. ${ }^{131}$ Citing sociologist Herbert J. Gans, Gates states:

Antipoverty programs have rarely been costed out to determine their benefits, such as what people employed in newly created jobs return tax rolls, what job and income grant programs save in spending for controlling and reducing crime and the physical and mental illnesses associated with poverty. If all the externalities, good and bad, associated with spending by and for (or against) the poor were added together, they would show that the country can afford far better antipoverty programs than it now provides. ${ }^{132}$

As for the national will, Gates argues that there are essentially two reasons that our country will not make a commitment to federal expenditures so that all poor families with children will be raised above the poverty line. First, there is an enduring ideology of the "undeserving poor." Second, poverty in the U.S. is mostly associated with blacks: there is a disproportionate number of blacks below the poverty line which creates the perception. Gates further states that there is an electoral allergy to race-specific programs, and that the liberals advocate in favor of universal social policies that unite blacks and whites in a common purpose. ${ }^{133}$

The problem with a universal social policy that does not acknowledge race is that it ignores the stark disparities in this country between races. Perhaps the thought process is like that of individuals or companies who don't pay their taxes; they hope the situation will go away if they just ignore it, only to find that interest and penalties have racked up along with the original debt. The U.S. pays a high price for its effort to discount the issue of race only fifty years after Brown v. Board of Education. It seems rather absurd to think that a mere forty-three years after the Civil Rights Act of 1964 that racial discrimination would fade away after more than 400 years of race-specific laws intended to suppress African-Americans. At most there are four or five

130. Roger Goldman \& David Gallen, Thurgood Marshall-Justice For All 202 (Carroll \& Graf Publishers, Inc. 1992).

131. HenRy LOUIS Gates, JR. \& CORNEl West, THE Future OF THE RACE 28 (Alfred A. Knopf. Inc. 1996).

132. Id. at 28-29, (citing Herbert J. Gans, The WAR Against the POOR: THE UNDERCLASS AND ANTIPOVERTY POLICY 117-18).

133. Gates \& West, supra note 131, at 29. 
generations of African-Americans who have benefited from affirmative action in higher education. At the same time, as Gates points out, for as many blacks who have risen to the middle class, there are just as many who have sunk further into poverty. ${ }^{134}$

Race is a hot-button issue for most Americans, and when one really pulls back all the layers, the characteristic of color is a contrived, divisive system which has served to enrich many whites around the country. The United States is not comfortable dealing with race in an honest manner because it stands for freedom, justice and liberty. To admit that a person's race can still determine her lot in life with regard to education, ability to be gainfully employed, or one's chances of having her children removed when there are allegations of neglect would mean that America does not live up to its universally revered standards. President Bill Clinton's Race Advisory Board concluded almost ten years ago that (a) racism is one of the most divisive forces in our society, (b) racial legacies of the past continue to haunt current policies and practices that create unfair disparities between minority and majority groups, (c) racial inequities are so deeply ingrained in American society that they are nearly invisible, and (d) most white Americans are unaware of the advantages they enjoy in this society and of how their attitudes and actions unintentionally discriminate against persons of color. ${ }^{135}$

3. Current Federal Legislation Contributes to Disproportionality and Requires Change

There is a well-founded argument that is supported by research and many prominent authorities in the field that current federal legislation, such as the Adoption Assistance and Child Welfare Act of 1980 (AACWA) and the Adoption and Safe Families Act of 1997 (ASFA), contributes to the disproportionality of African-American children in the foster care system and therefore should be reviewed for changes. ${ }^{136}$ ASFA established expedited time frames for placing children in permanent homes through reunification, adoption or guardianship and for terminating parental rights. ${ }^{137}$ ASFA also provided financial rewards to states for increasing the numbers of finalized adoptions

134. Gates \& West, supra note 131 , at 19-25.

135. Derald Wing Sue et al., Racial Microaggressions in Everyday Life, 62 AMERICAN PSYCHOLOGIST 271, 271-286 (2007).

136. Dorothy Roberts, Is There Justice in Children's Rights?: The Critique of Federal Family Preservation Policy, 2 U. PA. J. CONST. L. 112 (1999); Richard P. Barth, et al., From Anticipation to Evidence: Research on the Adoption and Safe Families Act, 12 VA. J. Soc. POL'Y \& L. 371 (2005); Kimberly Carpenter Emery, Family Ties Dismissed: The Unintended Consequences of AFSA, 12 VA. J. SOC. POL'Y \& L. 400 (2005); see also Christina White, Federally Mandated Destruction of the Black Family: The Adoption and Safe Families Act, $1 \mathrm{Nw}$. J. L. \& Soc. Pol'y 303 (2006); Ruth McRoy, Expedited Permanency: Implications for AfricanAmerican Children and Families, 12 Va. J. Soc. Pol'y \& L. 475 (2005).

137. The Adoption and Safe Families Act, supra note 120. 
through the adoption incentive payment program. The GAO Report notes that the 12-month timeline for reaching permanency on cases is not conducive to reunification with parents who are substance abusers or have complex issues concerning housing, prior criminal history and employment. ${ }^{138}$ Additionally, policies that limit child welfare funds for any other purposes other than maintenance payments to foster care families-preventative services, for example-are viewed as having a negative effect on the provision of services to African-American families. ASFA's promotion of quick termination of parental rights fails to balance the perceived need for permanency for the child with a parent's right to care for his or her child. ${ }^{139}$

The Multi-Ethnic Placement Act of 1994, as amended in 1996 by the Interethnic Adoption Provisions included in the Small Business Job Protection Act (MEPA-IEP), was intended to eliminate race-related barriers to adoption by prohibiting foster care and adoption agencies that receive federal funds from delaying or denying placement decisions on the basis of race, color, or national origin of either the adoptive or foster parent or child. ${ }^{140}$ MEPA-IEP also requires states to diligently recruit foster and adoptive parents who reflect the racial and ethnic diversity of the foster care population for a state to remain eligible for federal assistance for child welfare programs. The effect of ASFA coupled with MEPA-IEP resulted in many adoption placements of AfricanAmerican children with white families.

\section{A Federal Law Will Establish Necessary Funds to Ensure Change}

The money supporting the foster care system and providing services to families dealing with child abuse and neglect in the U.S. comes from various federal laws. The Child Abuse Prevention and Treatment Act (CAPTA), the Promoting Safe and Stable Families Act, the Social Security Act, and the Social Services Block Grant are federally funded mandates providing assistance to two million children. ${ }^{141}$ The solutions provided through AACWA2 require money - a resource that has yet to increase in the child welfare system to even keep up with the services that are supposed to be provided. A federal act will ensure a separate budget with which these issues can be addressed. The strategies used by states to address factors contributing to disproportionality include some of the tenets of the Act, such as training child welfare professionals to work across cultures, searching for fathers or paternal kin of foster children, and family group conferencing. Although some of the sections of AACWA2 could fall under other acts, it should be provided with its own funding.

138. GAO-07-816, supra note 12 , at 50-51;

139. Emery, supra note 136 , at $406-08$.

140. Multi-Ethnic Placement Act of 1994, Pub. L. No. 103-382, §§ 551-553 Stat. 1994.

141. Child Maltreatment 2005, supra note 74, at 77-78. 
The African-American Child Welfare Act is a social, economic, educational, and health care remedy for the issues plaguing poor AfricanAmericans in the United States. Many scholars argue that the black underclass in America was created in part by the legacy of slavery and Jim Crow laws and the desegregation of once-thriving black communities. ${ }^{142}$ The civil rights laws in the 1950s and 1960s have been considered less useful to the AfricanAmerican underclass than to the African-American middle class and working class because progress through these laws has been made mostly through lawsuits, which require time, flexibility, and money; all of which the underclass does not have. ${ }^{143}$ Congress, rather than the courts, is the more appropriate forum for African-Americans, especially the underclass, to seek solutions for the problems of disparate treatment and disproportionality in the child welfare, juvenile justice, and health care areas. ${ }^{144}$ Congress can initiate economic remedies because it is the only entity that has the power to tax and spend. Some may argue that laws providing for welfare and assistance to the poor should be adequate to address the problems of poor African-Americans. However, there is a significant disparate impact of welfare reform on minority families that has negatively affected poor people along racial and ethnic lines. ${ }^{145}$

Additionally, a federal law will guarantee funding for future research about disproportionality. States and private organizations that have completed their own analysis of the child welfare system have left many areas of research unexamined. More research is needed to examine the role of community protective factors on child maltreatment rates among minority and white families; to assess the impact of community characteristics on CPS decisionmaking on the structure and functioning of families in inner-city communities; and to examine the relationships between child welfare and external systems (such as public welfare, mental health, juvenile justice, and education) in order to determine the extent to which these systems contribute to racial disproportionality and disparities in child welfare. ${ }^{146}$

\section{THE CONSTITUTIONALITY OF THE AFRICAN-AMERICAN CHILD WELFARE ACT}

"Our interpretation of constitutional law is never through the eyes of

142. Roy L. Brooks, Race as an Under-Inclusive and Over-Inclusive Concept, 1 AFR.-AM. L. \& POL'Y REP. 9, 24 (1994); WILliam Julius Wilson, THE TRUly DisadvanTAGED: The INNER CITY, THE UNDERCLASS, AND PUBLIC POLICY, (University of Chicago Press 1987).

143. Brooks, supra note 142, at 26-27.

144. See Brooks, supra note 139 , at 24, n.79.

145. Risa E. Kaufman, The Cultural Meaning of the "Welfare Queen": Using State Constitutions to Challenge Child Exclusion Provisions, 23 N.Y.U. REV. L. \& SOC. CHANGE 301 (1997).

146. Hill, supra note 4 , at 38 . 
African Americans." 147

- Law Professor Kevin D. Brown

Indiana University School of Law

"It must be remembered that during most of the past 200 years the Constitution as interpreted by this court did not prohibit the most ingenious and pervasive forms of discrimination against the Negro. Now, when a state acts to remedy the effects of that legacy of discrimination, I cannot believe that this same Constitution stands as a barrier. At every point from birth to death the impact of the past is reflected in the still disfavored position of the Negro. In light of the sorry history of discrimination and its devastating impact on the lives of Negroes, bringing the Negro into the mainstream of American life should be a state interest of the highest order."

Thurgood Marshall dissent, Bakke decision (1978)

\section{A. Applying Strict Scrutiny Analysis}

Upon proposing a race-specific federal law, there must be an examination of whether the law is constitutional. The test for constitutionality of remedial, race-conscious government policies is strict scrutiny, which is the standard set forth in the Supreme Court cases City of Richmond v. J.A. Croson Co. and Adarand Constructors, Inc. v. Pena. ${ }^{149}$ In Adarand, the highest court determined that all governmental racial classifications are subject to the test of strict scrutiny - such classifications are constitutional only if they are narrowly tailored and they further a compelling governmental interest. If the substantive issue being addressed is important enough for the government to introduce race-based preferences, and there is evidence to show that there has been past discrimination to merit remediation, the interest may be deemed compelling. The majority in Croson set forth that there can not be only a generalized assertion of past discrimination, rather it must be specific enough for the court to make a finding of past discrimination. ${ }^{150}$ The statistics stated earlier in this article with respect to the disparate treatment of African-American families at each decision point in the child welfare system-reporting, investigations, substantiation, removal, provision of remedial services, placement in foster care, and exits from foster care-are particularized enough to satisfy this test.

Based on the court ruling in Croson, a state or local government can implement remedial affirmative action if it can show it became a "passive participant" in a system of racial exclusion practiced by private entities within

147. Martha Neil, Speakers Say Constitutional Law Hasn't Always Fostered Equality, 'Minority Opinion' A.B.A. J. (April 2006).

148. Regents of Univ. of Cal. v. Bakke, 438 U.S. 265 (1978)

149. City of Richmond v. J.A. Croson Co., 488 U.S. 469 (1989); Adarand Constructors, Inc. v. Pena, 515 U.S. 200 (1995).

150. Croson, 488 U.S. at 499 . 
its legislative jurisdiction. ${ }^{151}$ If discrimination is identified, race-neutral remedies must be utilized first. ${ }^{152}$ If race conscious programs are necessary in extreme cases, they must be narrowly tailored. While this is not exactly parallel to the actions of state child protection agencies, it can be argued that most states are "active participants" in a child welfare system that produces racially disparate outcomes for African-American children and families.

There are two basic questions that arise when considering whether the AACWA2 would violate the Fifth or Fourteenth Amendments. The first question to be addressed is whether the AACWA2 would systematically deny equal protection and due process rights to non-African-American families and children removed from the parents' home by the state. The second question is whether the AACWA2 would have a disparate impact on non-AfricanAmerican families and children such that it constructively denies equal protection and due process rights to any unprotected group. The answer to both questions is no. The same research and statistics that show disproportionality and disparity in treatment of African-American children supports the response to the first question. Caucasian families in the child welfare system seem to benefit from the cultural norms of the majority and the similarity in race to a large majority of mandatory reporters and CPS social workers. White families benefit from the provision of remedial services offered while their children remain in the home; therefore, many more of their families remain intact. Even while in the foster care system, white parents are offered more treatment options than African-American parents.

There is a question as to whether poor white children would be denied equal protection and due process rights because of the high prevalence of poor children and families of both races being involved with the child welfare system. If the same additional procedures were applied to all poor children across the board, there would likely be a vast improvement in outcomes of cases over time. However, class is not a protected category under the Fourteenth Amendment. The Supreme Court in San Antonio v. Rodriguez ruled that economic inequality is not constitutionally cognizable. ${ }^{153}$ Furthermore, the fact of the matter is that race and class are extremely intertwined in the U.S., mostly because past laws systematically excluded Blacks from acquiring property, an education, the right to vote, or access to institutions in order to build wealth. ${ }^{154}$ The impact of these discriminatory laws on the black family cannot be underestimated.

151. Id. at 507.

152. Id. at 492.

153. San Antonio Independent School District v. Rodriguez, 411 U.S. 1, (1973).

154. THE POLITICS OF LAW-A PROGRESSIVE CRITIQUE 89-116 (David Kairys, ed., 1982). 


\section{Maintaining the African-American Family: A Compelling State Interest}

When analyzing the African-American Child Welfare Act, the compelling governmental interest is the maintenance of family ties between AfricanAmerican children and their parents. The right to conceive and raise one's children is "essential, a basic civil right of man, and more precious than property rights." 155 Every parent has a fundamental right under the Fifth Amendment to raise their own children, and the U.S. Supreme Court established that substantive due process protects parents' fundamental right to the "care, custody, and management of their child." "S6 Similar to the governmental interest in alleviating institutional harms caused by forced assimilation of Native American children by federal agencies, there is also a governmental interest in alleviating institutional harms caused by disparate state intervention in the lives of African-American families, namely, the forced break of familial ties. African-American families should be given this due process through the African-American Child Welfare Act.

Professor Dorothy Roberts states, "racial disparity in the foster care population should cause us to reconsider the state's current response to child maltreatment." 157 She goes further to state that "viewing the racial disparity in the child welfare system as a group-based civil rights violation suggests an unorthodox form of redress." 158 Professor Roberts' well-researched book, Shattered Bonds-The Color of Child Welfare, sets forth the theory that America's child welfare policy is a means by which our government contends with Black child poverty. ${ }^{159}$ Are the liberty rights of African-American parents and children important enough for the government to introduce a race-based statute?

Although the current Supreme Court might argue that this Act is another form of discrimination because it sets forth a different legal standard or method of treatment of African-American families within the child welfare system, I argue that the Court's assertion in Parents Involved in Community Schools $v$. Seattle School District No. 1, et al., that discrimination can be stopped if we just stop discriminating, is absurd. ${ }^{160}$ Discrimination, at its very heart, is a manner of thinking, which ultimately develops into discriminatory words and then discriminatory actions. Equality begins when everyone believes that all

155. Stanley v. Illinois, 405 U.S. 645 (1972) (citing Meyer v. Nebraska, 262 U.S. 390 (1923)).

156. Santosky v. Kramer, 455 U.S. 745, 753 (1982) (citing Wisconsin v. Yoder, 406 U.S. 205 (1972)); Prince v. Massachusetts, 321 U.S. 158 (1944); Pierce v. Soc'y of Sisters, 268 U.S. 510 (1925); Meyer v. Nebraska, 262 U.S. 390 (1923).

157. Dorothy Roberts, Child Welfare and Civil Rights, 2003 U. ILL. L. REV. 171, 181 (2003).

158. Id. at 182.

159. Roberts, supra note 2, at 25-46.

160. Parents Involved in Community Schools v. Seattle School District No. 1, et al., $127 \mathrm{~S}$. Ct. 2738 (2007). 
people are created equal and, in this case, belief is an action, not just empty rhetoric propounded by members of an elite group that neither sees nor feels any direct impact of injustices meted out by state agencies.

Academics have further argued that the current conception of the familystate relationship supported by ASFA disproportionately affects poor Black children, and this fact poses a strong challenge to the foundational belief that the basic right to rear one's own child should not depend on a person's wealth or race. ${ }^{161}$ Since ASFA's focus on safety and permanency for children within a strict eighteen month time-frame has resulted in far more terminations of parental rights than adoptions, child welfare advocates have questioned whether government policy has moved too far away from guaranteeing a parent's right to parent his or her child and a child's right to grow up with his or her birth family. ${ }^{162}$ "The dramatic suffering of Black children has not penetrated the soul of this country to the point where we have developed a comprehensive and viable strategy to address and reverse these devastating consequences."163 Professor David Hall contends that black children have been invisible in American society because of whites' treatment of Blacks as less than people since the inception of our country, established through our Constitution and U.S. Supreme Court case law. ${ }^{164}$

\section{Narrowly Tailoring the Act to the Disparities}

The next question is whether the African-American Child Welfare Act is narrowly tailored enough to accomplish the compelling governmental interest while resisting Constitutional attack. Disparate treatment within the child welfare system touches six decision points: (1) reporting, (2) investigations, (3) substantiation, (4) provision of remedial services, (5) placement in foster care, and (6) exits from foster care. Research shows that five decision-making factors impact these decision points: (a) child safety, (b) child characteristics, (c) parent characteristics, (d) family characteristics, and (e) child welfare

161. Maxine Eichner, Children, Parents, and the State: Rethinking Relationships in the Child Welfare System, 12 VA. J. SOC. POL'Y \& L. 448, 458-59 (2005). Eichner states the familystate relationship is one where families are the responsibility of parents unless they fail to meet the societal standard, at which time the state enters in to protect the child (usually by removing them from their homes) and make minimal efforts for a period of time to "fix" whatever is wrong with the parents so that they can again raise their children without state aid.

162. Emery, supra note 136, at 406-08.

163. David Hall, Black Children and the American Dilemma: The Invisible Tears of Invisible Children, 26 B. C. THIRD WORLD L.J. 9, 12 (2006).

164. Id. at 11 ; U.S. CONST. art. $1, \S 3$, amended by U.S CONST. amend. XIV, $\S 2$ (clause stating that Blacks are only to be counted as three-fifths of a person for purposes of determining representation); Dred Scott v. Sandford, 60 U.S. 393, 452 (1856) (holding that no slave or descendant of a slave could ever be a U.S citizen, and finding that the Missouri Compromise of 1820 , which disallowed slavery in the newly emerging territories, unconstitutionally violated the due process clause of the Fifth Amendment). 
system characteristics. ${ }^{165}$ Racial bias or cultural misunderstanding among decision-makers is a major factor contributing to the disproportionate number of African-American children entering foster care. ${ }^{166}$ Child welfare officials and researchers say that many African-Americans in poor communities perceive child welfare caseworkers as more intent on separating AfricanAmerican parents from their children than on working within their communities to address child safety issues. ${ }^{167}$ Twenty-three child welfare directors report that they consider racial bias or cultural misunderstanding on the part of those reporting the abuse or neglect - such as teachers, medical professionals, or police officers-as a factor in the disproportionate representation of AfricanAmerican children entering foster care. ${ }^{168}$

The proposal in AACWA2 for cultural competence training in U.S. colleges and graduate schools that produce professionals who interact with children and families in the community, is narrowly tailored to remedy the issue of racial disparities in reporting. In order to impact how these professionals make decisions, there must be a change in how individuals are trained to think within institutions of higher education. Professionals in the public and private sectors, as well as mandated reporters (those professionals who require state licensure) need training on the issue of race, culture, and social policies.

Is there a less restrictive option? Perhaps it can be argued that only social workers who are employed by state agencies or other government workers should be required to have cultural competence training as part of the orientation process for their jobs. However, doctors, counselors, teachers, lawyers, nurses, and other mandated reporters are employed by private entities and are usually the initial point for decision-making in the child welfare context. A paradigm shift is necessary to change the manner of thinking within U.S institutions, private and public, which together have ultimately caused the disproportionately high number of African-American children languishing in the foster care system.

A change in the burden of proof at the initial removal hearing for AfricanAmerican families is also narrowly tailored to remedy the disproportionate number of child abuse and neglect referrals or reports, as well as the disparate treatment African-American families receive during the investigative process. The requirement that the state provide clear and convincing evidence of mistreatment will reduce the high number of unwarranted removals and increase the likelihood that all available services will be offered to keep African-American parents and children together.

165. HILL, supra note 4, at 17.

166. GAO-07-816, supra note 12 , at 22 .

167. Id. at 23 .

168. Id. at 24 . 
When caseworkers investigate, the use of the risk assessment tool will serve to help the state treat all families the same. This risk assessment tool will be a document consisting of a series of questions that the caseworker will have to answer regarding the possible risks posed to the child if she remains in the home. Of course, this requires appropriate supervision of caseworkers and a scheduled discussion regarding the issue of race, and how or if it played a part in the decision to substantiate (or not substantiate) the report of abuse or neglect. The use of the assessment tool is narrowly tailored to rectify the disproportionate numbers of substantiations of child maltreatment amongst African-American families. This method is one of the most consistent ways to determine if the training, "Undoing Racism," has short or long term effects on child welfare professionals.

Funding of AACWA2 is narrowly tailored to address the differential treatment of African-American families in the provision of remedial services. Additional higher quality services such as assistance with housing, job training, parenting coaches, and community wrap around programs must be funded in order to impact the disparate number of African-American families in the child welfare system. Adequate funding will also ensure that the service providers utilized are culturally competent, which should increase the likelihood that African-American parents will successfully complete their services. The funding ultimately would result in quicker exits from foster care for AfricanAmerican children.

The requirements regarding early identification of fathers and paternal relatives and the early intervention model are specifically designed to reduce the number of foster care placements for African-American children by identifying a relative earlier in the case with whom a child can be temporarily or permanently placed. Increasing reasonable efforts to contact alleged fathers and incarcerated fathers will increase the likelihood that African-American children will maintain their family ties and parents will be able to assert their parental rights to raise their children or have them placed with a relative or kin person who is trustworthy.

\section{CONCLUSION}

The African-American Child Welfare Act passes the strict scrutiny test in that it is justified by a compelling governmental interest and narrowly tailored to accomplish a remedial purpose. The factual predicate that supports the AACWA2 establishes the type of identified past discrimination in child welfare that would authorize race-based relief under the Fourteenth Amendment of the Equal Protection Clause. Equal protection implies that there is equality among children and parents at the starting point of the process in the child welfare system. It defies logic to fail to acknowledge the vast differences that exist among black families and white families in America. Many would argue that 
these differences have nothing to do with the law, but more to do with economics and the class structure in the United States. The bottom line is that the economics and class structure of this country have been built upon the widespread institution of racism, which has been supported by the law since this country's inception up until a little over forty years ago. It is logical to ask the question, if the African-American Child Welfare Act was applied to all families, regardless of race, could it achieve the same goal? In an ideal world, the answer would be yes, but the reality of the situation points in the opposite direction.

In Martin Guggenheim's book, What's Wrong With Children's Rights?, there is a modified version of a folk parable where people in a town are feverishly working to save babies floating down a cold stream. ${ }^{169}$ A visitor to the town is asked to help in the crisis, and he quickly learns that the townspeople have been picking up babies at all hours of the day and night. He refuses to help, and the townspeople get indignant. "Don't you care?" The visitor responds, "It strikes me that your efforts are ultimately inadequateobviously somebody keeps putting those babies in the stream, so I'm going to go upstream, find the source, and put an end to it once and for all." The story points to an important question: Do we care enough to put more efforts into preventing children from entering the foster care system than into maintaining the institution itself? I do. AACWA2 is my recommendation to stop the flow of African-American children from coming into the foster care system in the first place. If we can reduce the number of children that enter the system, as well as work on the opposite end to place children who are languishing in foster care either back with their families, with a family member, or into an adoptive home, we can actively address the problem of disproportionality in the child protection system.

169. MARTIN GugGENHEIM, What's WRONG With CHILDREN's RIGHTS? 174 (Harvard University Press 2005). 